\title{
ECOLOGICAL DISTRIBUTION OF STREAM MACROALGAL COMMUNITIES FROM A DRAINAGE BASIN IN THE SERRA DA CANASTRA NATIONAL PARK, MINAS GERAIS, SOUTHEASTERN BRAZIL
}

\author{
NECCHI-JÚNIOR, O., ${ }^{1}$ BRANCO, L. H. Z. ${ }^{1}$ and BRANCO, C. C. Z. ${ }^{2}$ \\ ${ }^{1}$ Universidade Estadual Paulista, Depto. Zoologia e Botânica, São José do Rio Preto, SP, Brazil \\ ${ }^{2}$ Universidade Estadual do Centro-Oeste \\ Correspondence to: Orlando Necchi Jr., Universidade Estadual Paulista, Depto. Zoologia e Botânica, \\ Rua Cristóvão Colombo, 2265, CEP 15054-000, São José do Rio Preto, SP, Brazil, \\ e-mail: orlando@bot.ibilce.unesp.br \\ Received Juny 18, 2002 - Accepted August 29, 2002 - Distributed November 30, 2003
}

(With 3 figures)

\begin{abstract}
Twelve stream segments were sampled four times in 1998-1999 (one sampling per season) in the drainage basin of the upper São Francisco River (19 $45^{\prime}-21^{\circ} 25^{\prime}$ S, $\left.49^{\circ} 05^{\prime}-51^{\circ} 30^{\prime} \mathrm{W}\right)$, situated in Serra da Canastra National Park, at altitudes ranging from 1,175 to $1,400 \mathrm{~m}$. The macroalgae survey resulted in 30 species, with a predominance of Cyanophyta $(12$ species $=40 \%)$ and Chlorophyta $(11$ species $=36.5 \%)$ and a lower proportion of Rhodophyta (seven species $=23.5 \%$ ). Two species, Klebsormidium rivulare (Chlorophyta) and Kyliniella latvica (Rhodophyta), were new records for Brazil. Capsosira sp. and Stigonema sp. (Cyanophyta) and the "Chantransia" stage of Batrachospermum (Rhodophyta) were the most widespread macroalgae, occurring in six sampling sites, whereas 11 species were found at only one site. The proportion of macroalgal morphological types were as follows: mats (33\%), free filaments (27\%), gelatinous filaments $(27 \%)$, crusts $(7 \%)$, tufts $(3 \%)$, and gelatinous colonies $(3 \%)$. The flora revealed few species in common (4\%-8\%) with stream macroalgae from other Brazilian regions. The macroalgal communities proved to have species richness values close to the highest values reported in previous studies. The patterns typical for stream macroalgal communities (patchy distribution and dominance of few species) were also found in this basin. However, the stream variables most influential in macroalgal distribution in this study (rocky substratum, low $\mathrm{pH}$, high COD, water color, and current velocity) were essentially the same that best describe the limnological characteristics of this lotic ecosystem. In addition, this combination of variables differed sharply from results of previous studies in other Brazilian stream ecosystems.
\end{abstract}

Key words: ecological distribution, macroalgae, mountain stream, highland grassland.

\section{RESUMO}

\section{Distribuição de macroalgas lóticas de uma bacia de drenagem no Parque Nacional da Serra da Canastra, Minas Gerais, Brasil}

Doze segmentos de riachos foram amostrados quatro vezes em 1998-1999 (uma amostragem em cada estação) na bacia de drenagem do alto rio São Francisco (19² $\left.45^{\prime}-21^{\circ} 25^{\prime} \mathrm{S}, 4^{\circ} 05^{\prime}-51^{\circ} 30^{\prime} \mathrm{W}\right)$, situado no Parque Nacional da Serra da Canastra, em altitudes de 1.175 a $1.400 \mathrm{~m}$. O levantamento das macroalgas resultou em 30 espécies, com predominância de Cyanophyta $(12$ espécies $=40 \%)$ e Chlorophyta (11 espécies $=36,5 \%$ ) e menor proporção de Rhodophyta (sete espécies $=23,5 \%)$. Duas espécies, Klebsormidium rivulare (Chlorophyta) e Kyliniella latvica (Rhodophyta), constituem novos registros para o Brasil. Capsosira sp. e Stigonema sp. (Cyanophyta) e o estágio "Chantransia" de 
Batrachospermum (Rhodophyta) foram as macroalgas mais amplamente distribuídas, ocorrendo em 6 pontos de amostragem, enquanto 11 espécies foram encontradas em apenas um ponto. As proporções de tipos morfológicos de macroalgas foram as seguintes: emaranhado de filamentos (33\%), filamentos livres (27\%), filamentos gelatinosos (7\%), crostas (7\%) e tufos e colônias gelatinosas (3\%). A flora teve poucas espécies em comum (4\%-8\%) com macroalgas lóticas de outras regiões brasileiras. As comunidades de macroalgas mostraram-se ricas, com valores de riqueza de espécies próximos aos mais altos anteriormente reportados. Os padrões típicos para comunidades de macroalgas lóticas de distribuição em mosaico e dominância de poucas espécies também foram encontrados nessa bacia. Entretanto, as variáveis ambientais mais influentes sobre a distribuição de macroalgas neste estudo (substrato rochoso, baixos valores de $\mathrm{pH}$ e altos de DQO, cor da água e velocidade da correnteza) foram essencialmente as mesmas que melhor descreveram as características limnológicas desse ecossistema lótico. Além disso, essa combinação de variáveis foi nitidamente diferente dos resultados de estudos anteriores em outros ecossistemas lóticos brasileiros.

Palavras-chave: distribuição ecológica, macroalgas, riacho de montanha, campo de altitude.

\section{INTRODUCTION}

Important studies on stream macroalgal communities have been developed in boreal, temperate, or tropical regions of various continents: Australasia (Biggs \& Price, 1987; Entwisle, 1989), Europe (Holmes \& Whitton, 1981; Johansson, 1982; John \& Moore, 1985; Kawecka, 1980, 1981; and several examples in Whitton, 1984), North America (Sheath \& Burkholder, 1985; Sheath \& Cole, 1992; Sheath et al., 1986, 1989, 1996), and South America (Branco \& Necchi, 1996, 1998; Necchi et al., 1995, 2000a).

Contributions on the ecological distribution of macroalgal communities in mountain or high latitude streams are comparatively fewer. Sheath et al. (1996) reported data on tundra stream macroalgae in the Arctic (North America), whereas sparse mountain regions have been investigated in Europe (Kawecka \& Eloranta, 1987; Pfister, 1992, 1993; Uehlinger, 1991), North America (Meegan \& Perry, 1996; Vavilova \& Lewis, 1999; Ward 1986; Wehr, 1981), and Asia (Ormerod et al., 1994). Similar investigations in tropical mountain regions are much scarcer (Pentecost et al., 1997). Such studies are relevant because they make it possible to analyze environmental and geographic distributional patterns over widely contrasting climatic and altitudinal conditions, varying from subtropical or low altitude to temperate, sub-alpine, or high altitude. According to Ward (1994), rhitral streams in alpine catchments are characterized by soft water, and the flora is constituted by bryophytes, macroalgae (chrysophytes, chlorophytes, cyanophytes, and rhodophytes), and epiphytic and epilithic diatoms.
In Brazil, research in mountain streams is still in a very early stage. The few contributions deal with limnological characteristics (Necchi et al., 2000 b) or descriptive aspects of habitat and benthic fauna (Callisto et al., 2001; Galdean et al., 2001) of mountainous regions of Minas Gerais State, southeastern Brazil.

Considering the paucity of information, the aim of the present study was to carry out an analysis of species richness and abundance for macroalgal communities and their relationships with environmental variables from a drainage basin in a grassland field located within the Serra da Canastra National Park, Minas Gerais State, southeastern Brazil. We hypothesized that differences would be found for these parameters of community structure and for macroalgal species composition in comparison with other Brazilian regions distinct in climatic, geological, and limnological characteristics (Necchi et al., 2000b) and studied with the same aims and methods (Branco \& Necchi, 1996, 1998; Necchi et al., 1994, 2000a).

\section{MATERIAL AND METHODS}

The characterization of the study area in the park was presented in a previous paper (Necchi et $a l ., 2000 \mathrm{~b})$. The area comprises the drainage basin of the upper São Francisco River (1945'-21 '25'S, $\left.49^{\circ} 05^{\prime}-51^{\circ} 30^{\prime} \mathrm{W}\right)$, situated entirely within the limits of the Serra da Canastra National Park at altitudes ranging from 1,175 to $1,400 \mathrm{~m}$. The vegetation is basically made up of highland grasslands, with riparian vegetation occurring sparsely along some segments of the main river courses. Soil is mostly 
shallow and poorly drained, with rocky emergences in large areas and on most of the river banks.

Species richness and abundance of stream macroalgae were investigated in 12 sampling sites distributed throughout the drainage basin of the São Francisco River (Fig. 1). These stream segments were sampled four times during one year (1998-1999), once per season: May 26-29 (fall), September 4-7 (winter), November 4-6 (spring), and February 4-7 (summer). Each sampling site consisted of $10 \mathrm{~m}$ reaches along the stream banks, which were thoroughly examined for macroalgae presence and abundance estimated in terms of percentage cover as described by Sheath \& Burkholder (1985). We adopted the concept of macroalga and the respective morphological types, as defined by Sheath \& Cole (1992).

The following stream variables were measured (as previously described by Necchi et al., 2000b): temperature, specific conductance, turbidity, current velocity, water color, $\mathrm{pH}$, dissolved oxygen, total nitrogen and phosphorus, nitrate, ammonium, orthophosphate, calcium, iron, potassium, and chemical oxygen demand (COD). Temperature, conductance, turbidity, $\mathrm{pH}$, and oxygen were measured with a Horiba U-10 water checker equipped with a multiple probe, whereas measurements of current velocity were taken with a General Oceanics 2030R mechanical flowmeter immediately below the water surface. The remaining variables were measured with a Merck SQ-118 spectrophotometer, and spectroquant specific reagents from samples kept refrigerated from one to three months. In addition, slope, substrata types, width, depth, and shading were also analyzed at all sampling sites, respectively, with a Sokkiska clinometer, using visual estimate and comparison with particle size classes, a measuring tape, and classification in four shading classes (Necchi et al., 2000b).

Differences in means for macroalgal species richness and abundance (percent cover) were tested by one-way analysis of variance (ANOVA) and Newman-Keuls multiple comparison test (Zar, 1999). Relationships of species richness and abundance with stream variables were evaluated by Pearson momentproduct correlation coefficient, whereas multiple linear regression analysis was applied in order to evaluate the combined effect of the most closely related variables (Zar, 1999). We applied parametric statistical tests because the variables followed normal distribution according to graphical assessment of normality based on the fitting (regression) curves for frequency distributions (Zar, 1999). Canonical correspondence analysis (CCA, Ter Braak, 1986) was applied to the macroalgal (species richness, abundance, and taxa) and environmental data, using mean values for all 12 sites. Matrices were constructed with values standardized by ranges. Environmental variables used in the CCA were selected by exploratory statistics (correlation and regression analyses and a CCA with the complete set of variables) in order to avoid redundant and weak characters. The analyses were performed with the statistical packages Statsoft Statistica (version 6.0) and KCS (Kovach Computing Services) Multivariate Statistical Package (MVSP version 3.1).

\section{RESULTS}

The survey of macroalgal species in the upper São Francisco River basin resulted in 30 species (Table 1), with a predominance of Cyanophyta (12 species $=40 \%)$ and Chlorophyta (11 species = $36.5 \%)$ and a lower proportion of Rhodophyta (7 species $=23.5 \%$, plus the "Chantransia" stage). Two species, Klebsormidium rivulare (Chlorophyta) and Kyliniella latvica (Rhodophyta), are new records for Brazil. Unidentified species of blue-green algal genera (Capsosira, Hapalosiphon, Scytonema and Stigonema) may be additional new records for the Brazilian macroalgal flora or even species new to science. Cyanophyta was also the predominant algal division $(50 \%)$ in terms of species richness per sampling site, followed by Chlorophyta (33\%) and Rhodophyta (17\%).

The genera Batrachospermum (Rhodophyta), Scytonema (Cyanophyta), and Microspora (Chlorophyta) were the best represented with six, four, and three species, respectively (Table 1). Capsosira sp. and Stigonema sp. (Cyanophyta) and the "Chantransia" stage of Batrachospermum (Rhodophyta) were the most widespread macroalgae, occurring in six sampling sites. Other species were also widely distributed in the basin (occurrence in five sites): Hapalosiphon sp. and Rivularia sp. (Cyanophyta), and M. quadrata and M. willeana (Chlorophyta). On the other hand, 11 species were found at only one site. In terms of seasonality, 13 species $(43 \%)$ occurred throughout the year, whereas nine $(30 \%)$ were found in only one season, with no trend. The proportion of macroalgal morphological types were as follows: mats (33\%), free filaments $(27 \%)$, gelatinous filaments $(27 \%)$, crusts $(7 \%)$, tufts $(3 \%)$, and gelatinous colonies $(3 \%)$. 


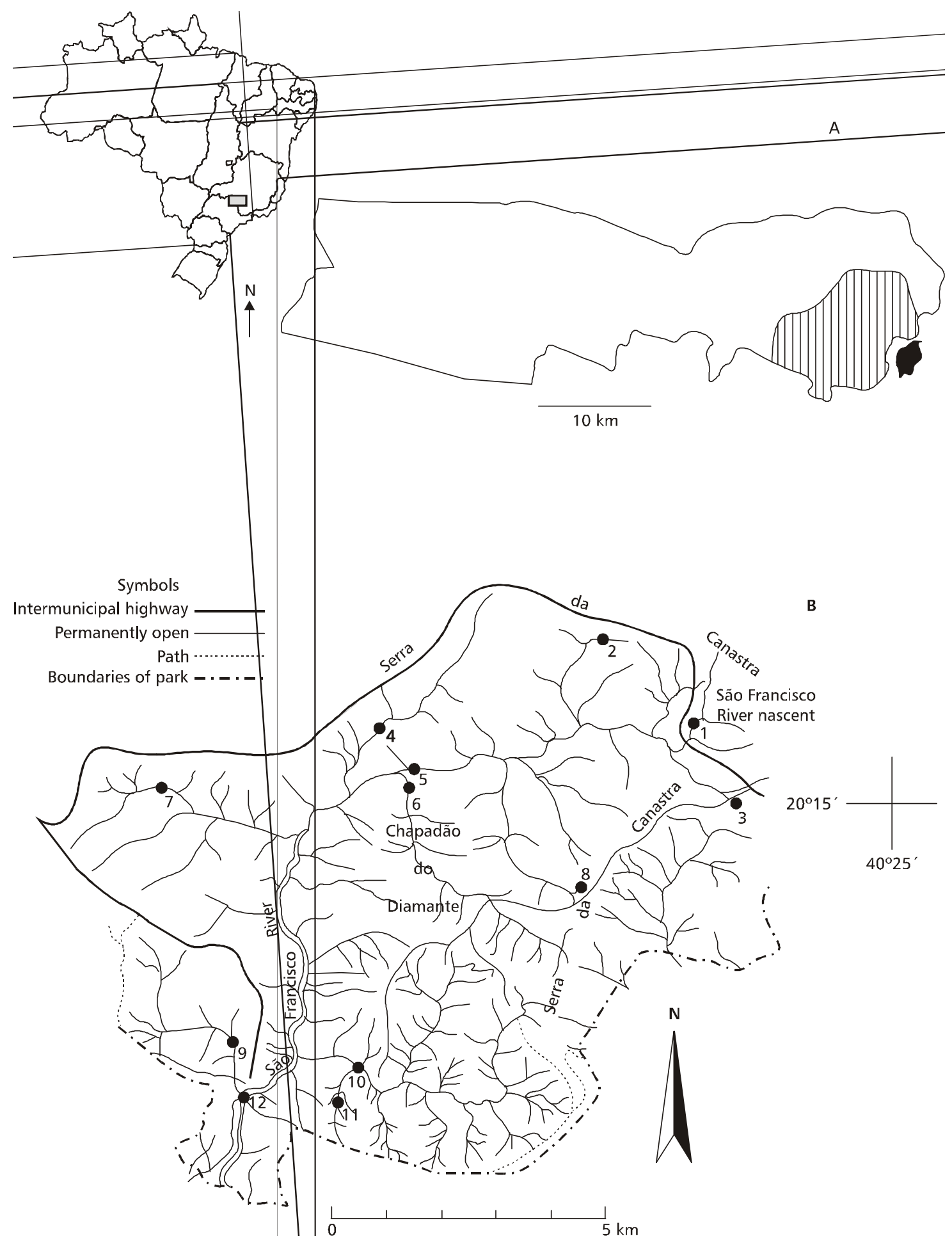

Fig. 1 - A - Location of the Serra da Canastra National Park in southeastern Brazil and general sketch of the area, indicating the area of São Francisco drainage basin. B - Detail of the São Francisco drainage basin showing the sampling sites. 


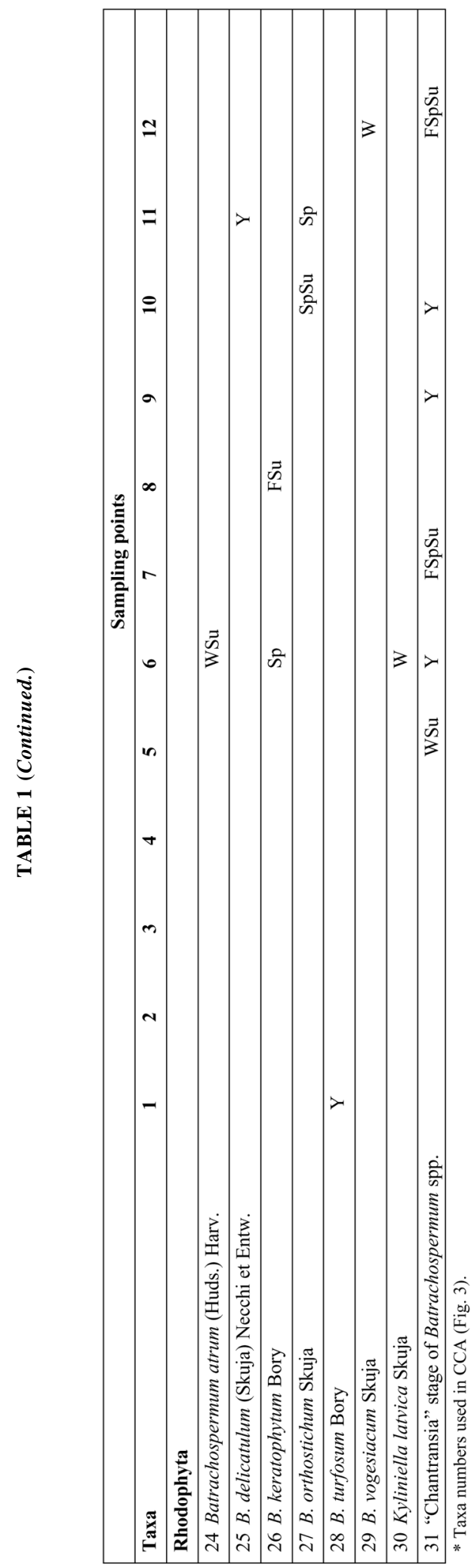

Braz. J. Biol., 63(4): 635-646, 2003 
The following results were observed for environmental variables: 1) species richness per sampling site was positively correlated $(\mathrm{p}<0.05)$ to current velocity $(\mathrm{r}=0.48-0.59)$ and $\mathrm{pH}(\mathrm{r}=0.34$ $0.39)$, and negatively to color $(\mathrm{r}=0.34-0.41)$ and COD $(r=0.36-0.49)$, whereas percent cover had no correlation with stream variables; 2 ) multiple regression revealed that current velocity, $\mathrm{pH}$, color, and COD accounted for $30 \%$ of species richness fluctuations.

The following patterns of macroalgal communities per sampling site and season were evidenced (Tables 2-3, Fig. 2): 1) species richness ranged from one to nine (overall mean $=3.9$ ) with a normal distribution; the highest values were found in winter and the lowest in fall, but with no significant differences; species richness was positively correlated ( $\mathrm{r}=0.42, \mathrm{p}<0.01)$ with percent cover; 2 ) percent cover also revealed a normal distribution, with wide variation $(0-65 \%$, overall mean $=13 \%)$; the highest values were observed in fall and winter, and the lowest in spring; there were no significant differences among seasons; 3) sampling sites 7, 9, and 11 had high species richness (mean $>6.0)$ and abundance (mean $\%$ cover $\geq 20 \%$ ), whereas sites 3,5 , and 8 had low richness (mean $\leq 2.0$ ) and abundance (mean $\%$ cover $\leq 2 \%$ ).

The CCA results (Table 4, Fig. 3) showed that rocky substratum, $\mathrm{pH}$, current velocity, water color, and COD were the most influential environmental variables in explaining the association of sampling sites and macroalgal species.
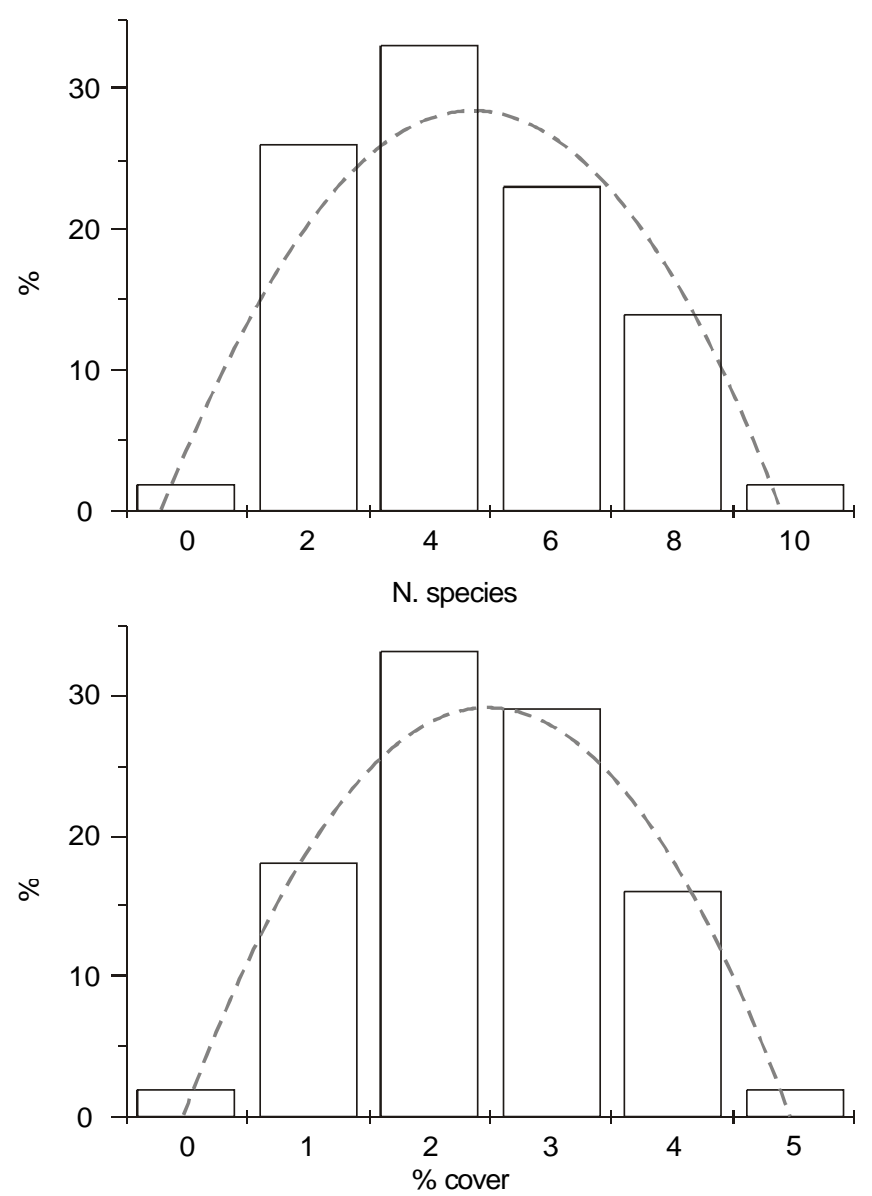

Fig. 2 - Frequency distributions of macroalgal species richness and abundance (\% cover) per sampling site in the upper São Francisco River basin, Serra da Canastra National Park. Dotted lines represent the fitting (regression) curves. Values for $\%$ cover: $1=<1 \%, 2=1 \%-10 \%, 3=11 \%-25 \%, 4=26 \%-50 \%, 5=51 \%-75 \%$. 
The CCA delineated a large group of sampling sites mostly concentrated on the left (negative) side of axis 1 and with a trend of highest values of algal cover percent ( $8 \%-32 \%)$ in sampling sites with higher proportions $(77 \%-100 \%)$ of bedrock (sites 1, 2, 7, 11, Table 3, Fig. 3A). Sites 6 and 8 did not group with any other and were positioned on the right (positive) side of axis 1 , basically due to their low cover percent values $(<$ $8 \%)$ and bedrock $(<65 \%)$; site 8 also had the lowest values of current velocity and $\mathrm{pH}$. The CCA also showed a large group of species mostly concentrated on the left (negative) side of axis 1, indicating relatively similar trends for environmental variables. Some species (e.g., $B$. turfosum and Hapalosiphon sp.) clearly tended to occur in stream segments with higher values for COD and water color and lower $\mathrm{pH}$, whereas others (e.g., $H$. pumilus and $M$. willeana) showed an inverse trend (Table 1, Fig. 3B). On the other hand, S. fritschii and $B$. keratophytum did not group with the other species essentially because of common occurrence in site 8 , while $B$. atrum, $K$. latvica, and $S$. dubia were apart from the other species, and exclusive to site 6 .

TABLE 2

Overall and seasonal values (mean \pm standard-deviation) of species richness and abundance of macroalgal communities in the upper São Francisco River basin, Serra da Canastra National Park. $\mathbf{N}=12$ unless otherwise indicated.

\begin{tabular}{|c|c|c|}
\hline Season & Species richness & Percent cover \\
\hline Overall $^{1}$ & $3.9 \pm 2.3$ & $13 \pm 14$ \\
\hline Fall & $3.7 \pm 2.1$ & $17 \pm 19$ \\
\hline Winter $^{2}$ & $4.3 \pm 1.9$ & $16 \pm 10$ \\
\hline Spring & $4.0 \pm 2.9$ & $9 \pm 11$ \\
\hline Summer & $3.8 \pm 2.1$ & $12 \pm 15$ \\
\hline
\end{tabular}

TABLE 3

Values (mean \pm standard-deviation) of species richness and abundance of macroalgal communities per sampling site in the upper São Francisco River basin, Serra da Canastra National Park. $\mathbf{N}=4$ unless otherwise indicated. Same letters indicate no significant difference by Newman-Keuls test.

\begin{tabular}{|c|c|c|}
\hline Site & Species richness & Percent cover \\
\hline 1 & $2.5 \pm 1.3(\mathrm{a})$ & $32.0 \pm 30.0(\mathrm{c})$ \\
\hline $2^{*}$ & $1.7 \pm 1.2(\mathrm{a})$ & $8.0 \pm 13.0(\mathrm{~b})$ \\
\hline $3^{*}$ & $1.7 \pm 1.5(\mathrm{a})$ & $0.5 \pm 0.5(\mathrm{a})$ \\
\hline 4 & $4.8 \pm 0.5(\mathrm{~b})$ & $9.0 \pm 13.0(\mathrm{~b})$ \\
\hline 5 & $1.5 \pm 0.6(\mathrm{a})$ & $2.0 \pm 3.0(\mathrm{a})$ \\
\hline 6 & $3.3 \pm 1.7(\mathrm{~b})$ & $2.4 \pm 1.0(\mathrm{a})$ \\
\hline 7 & $7.8 \pm 1.0(\mathrm{c})$ & $30.0 \pm 5.0(\mathrm{c})$ \\
\hline $8^{*}$ & $2.0 \pm 1.0(\mathrm{a})$ & $1.0 \pm 2.0(\mathrm{a})$ \\
\hline 9 & $6.5 \pm 1.3(\mathrm{c})$ & $21.0 \pm 6.0(\mathrm{c})$ \\
\hline 10 & $3.8 \pm 0.5(\mathrm{~b})$ & $12.0 \pm 6.0(\mathrm{~b})$ \\
\hline 11 & $6.3 \pm 1.3(\mathrm{c})$ & $20.0 \pm 5.0(\mathrm{c})$ \\
\hline 12 & $4.0 \pm 0.8(\mathrm{~b})$ & $12.0 \pm 8.0(\mathrm{~b})$ \\
\hline
\end{tabular}




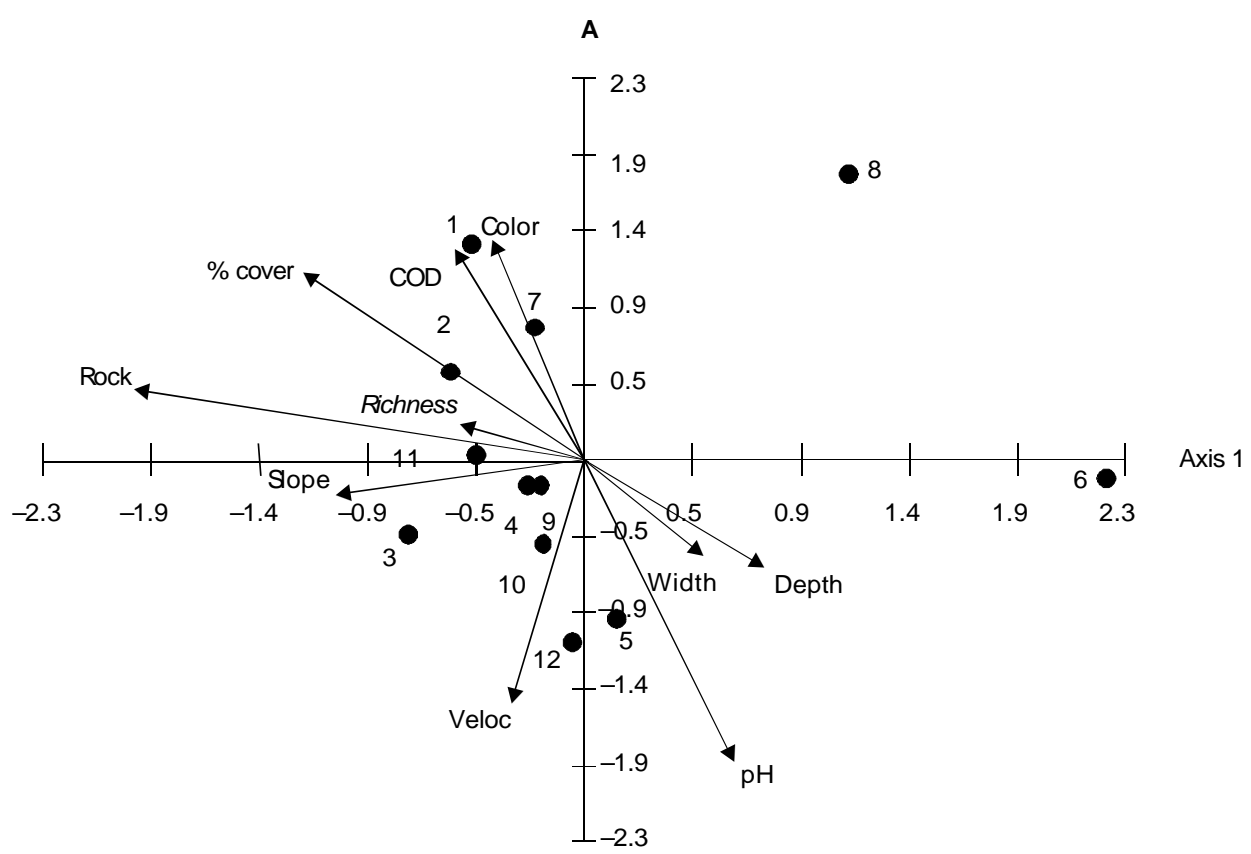

Axis 2

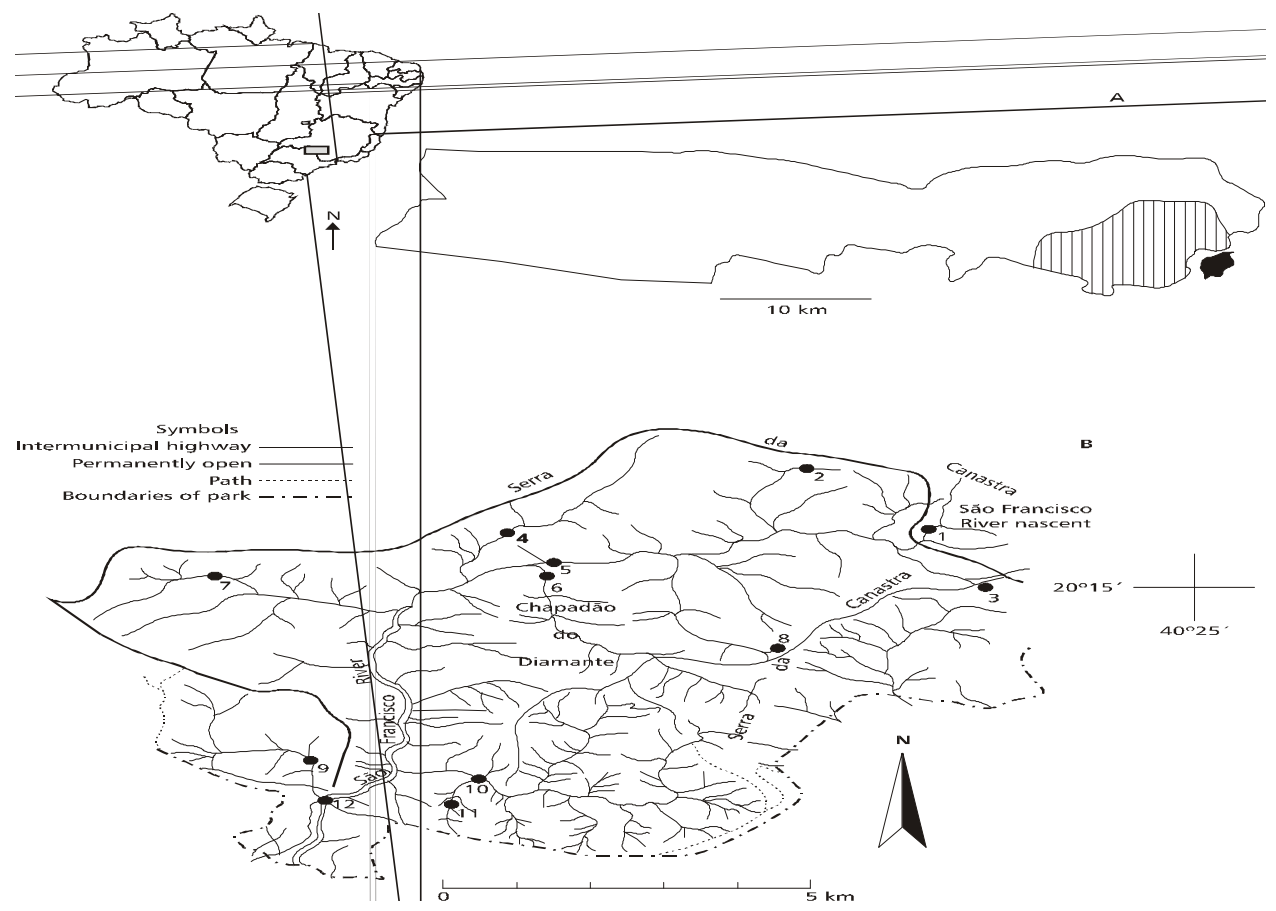

Fig. 3 - Canonical Correspondence Analysis (CCA) biplots for the 12 sampling sites (A) and macroalgal species (B) in the upper São Francisco River basin, Serra da Canastra National Park. Environmental variables and macroalgal species richness and abundance (\% cover) are represented by arrows. Vector labels (same as on Fig. A) were omitted for clarity. Taxa numbers according to Table 1 . 
TABLE 4

Summary of Canonical Correspondence Analysis (CCA) results for sampling sites and macroalgal species. PVE percentage of variance explained; TVE - total variance explained.

\begin{tabular}{|c|c|c|c|c|}
\hline Axis & Eigenvalue & PVE & TVE & Correlation - r (axis x environmental parameter) \\
\hline 1 & 0.65 & 19.3 & 19.3 & Rock $(-0.69)$ \\
\hline 2 & 0.51 & 15.1 & 34.4 & $\mathrm{pH}(-0.74)$, veloc. $(-0.59)$, color $(0.54)$, COD $(0.52)$ \\
\hline
\end{tabular}

\section{DISCUSSION}

The predominance of Cyanophyta and Chlorophyta in relation to other algal divisions essentially agree with results of other major surveys of stream macroalgal communities (24\%-35\% and $35 \%-37 \%$, respectively, Sheath \& Cole, 1982 ; Necchi et al., 2000a). The proportions of macroalgal morphological types in this study differ sharply from data presented or compiled in previous investigations (Sheath \& Cole, 1992; Necchi et al., 2000a): mats (42\%-52\%), gelatinous colonies (12\%-23\%), gelatinous filaments $(11 \%-13 \%)$, free filaments $(8 \%$ $15 \%)$, tissue-like (3\%-7\%), tufts (4\%-14\%), and crusts $(1 \%-2 \%)$. The most notable differences were the lower proportions of mats, tufts, and gelatinous colonies and the higher ones of free and gelatinous filaments and crusts. All morphological types but free filaments can be considered as relatively well adapted to cope with the mechanical effect provoked by current velocity (Sheath \& Hambrook, 1988; Sheath \& Cole, 1992). The adaptations are basically related to avoidance of flow-related breaking stress of the generally filamentous forms whether by densely intermingling (mats), encasing in a gelatinous matrix (gelatinous colonies or filaments), or growing entirely or partly within the boundary layer close to substrata (crusts and tufts). This aspect seems to be important in the macroalgal communities of mountain regions, typically subjected to moderate or high flows.

The most frequently encountered genera and species in this study were not reported as widespread macroalgae in other general surveys (Biggs \& Price, 1987; Entwisle, 1989; Sheath \& Cole, 1992; Necchi et al., 2000a). On the other hand, they are commonly reported in floras of high latitudes (Sheath et al., 1996) or mountainous regions (Vavilova \& Lewis, 1999; Pfister, 1992; Wehr, 1981). Some species (e.g., B. keratophytum, B. turfosum, and $M$. quadrata) are often found in humic waters (low $\mathrm{pH}$, brown water, high dissolved organic matter, and low availability of inorganic nutrients), similar to those prevailing in this basin (Necchi et al., 2000b). The exclusive occurrence of heterocytous blue-green algal species, presumably due to low inorganic nitrogen availability is noteworthy. The entire flora revealed relatively few species in common (4\%-8\%) with stream macroalgae from other Brazilian regions (Branco \& Necchi, 1996, 1998; Necchi et al., 1994, 2000a). This agrees with our initial hypothesis of low floristic similarity with other regions studied. Among the species identified, 10\% were considered as widely distributed in Brazilian tropical regions, whereas $30 \%$ were regarded as widespread in temperate regions. Due to scarcity of information, we could conclude nothing so far about endemism, but it is reasonable to presume that some species herein reported are likely found in other mountainous regions with similar characteristics.

The macroalgal communities in the region studied proved to be rich, as indicated by the species richness values per sampling site, which were close to the highest values reported in previous studies (1.8-5.6, Sheath \& Cole, 1982; Branco \& Necchi, 1996, 1998; Necchi et al., 1994, 2000a). Percentage values were within the range found in those studies $(6 \%-43 \%)$. The general patterns reported for stream macroalgal distribution (Sheath \& Cole, 1982; Necchi et al., 2000a) of patchiness (indicated by the fact that the most abundant communities were also the most diverse) and of strong dominance by few species were observed at most sites, which confirms that they are generally typical of stream macroalgal communities (Sheath et al., 1986). On the other hand, the stream variables most influential on macroalgal distribution in this study (rocky substratum, low $\mathrm{pH}$, high $\mathrm{COD}$, water color, and 
current velocity) were essentially the same that best described the limnological characteristics of this unique lotic ecosystem (Necchi et al., 2000a). In addition, this combination of variables was sharply different from results of previous studies in other Brazilian stream ecosystems (Branco \& Necchi, 1996, 1998; Necchi et al., 1994, 2000a).

Acknowledgments - This research was supported by a FAPESP grant-in-aid (98/01108-8) to ONJ and CNPq research grants to ONJ (520551/96-6), LHZB (300128/97-5), and CCZB (520257/01-4). We greatly appreciated field work help by Marcelo R. Zucchi and Jeferson L. Pereira, Maria Helena Carabolante for the help in laboratory analyses, and the staff of Serra da Canastra National Park for support during field trips.

\section{REFERENCES}

BIGGS, B. J. F. \& PRICE, G. M., 1987, A survey of filamentous algal proliferations in New Zealand rivers. New Zeal. J. Mar. Freshwat. Res., 21: 175-191.

BRANCO, C. C. Z. \& NECCHI, O. Jr., 1996, Distribution of stream macroalgae in the eastern Atlantic Rainforest of São Paulo State, southeastern Brazil. Hydrobiologia, 333: 139-150.

BRANCO, L. H. Z. \& NECCHI, O. Jr., 1998, Distribution of macroalgae in three tropical drainage basins in São Paulo State, southeastern Brazil. Arch. Hydrobiol., 142: 241-256.

CALLISTO, M., MORENO, P. \& BARBOSA, F. A. R., 2001, Habitat diversity and benthic functional trophic groups at Serra do Cipó, southeast Brazil. Rev. Bras. Biol., 61: 259-266.

ENTWISLE, T. J., 1989, Macroalgae in Yarra River basin: flora and distribution. Proc. Roy. Soc. Victoria, 101: 1-76.

GALDEAN, N., CALlisto, M. \& BARBOSA, F. A. R., 2001, Biodiversity assessment of benthic macroinvertebrates in altitudinal lotic ecosystems of Serra do Cipó (MG, Brazil). Rev. Bras. Biol., 61: 239-248.

HOLMES, N. T. H. \& WHITTON, B. A., 1981, Phytobenthos of River Tees and its tributaries. Freshw. Biol., 11: 43-60.

JOHANSSON, C., 1982, Attached algal vegetation in running water of Jämtland,Sweden. Acta Phytogeogr. Suec., 74: 1-84.

JOHN, D. M. \& MOORE, J. A., 1985, Observations on the phytobenthos of the freshwater Thames, I: The environment, floristic composition and distribution of the macrophytes (principally macroalgae). Arch. Hydrobiol., 102: 435-459.

KAWECKA, B., 1980, Sessile algae in European mountain streams 1. The ecological characteristics of communities. Acta Hydrobiol., 22: 361-420.

KAWECKA, B., 1981, Sessile algae in European mountain streams 2. Taxonomy and autoecology. Acta Hydrobiol., 23: $17-46$.

KAWECKA, B. \& ELORANTA, P., 1987, Communities of sessile algae in some small streams of Central Finland. Comparison of algae of the high mountains of Europe and those in northern region. Acta Hydrobiol., 29: 403-315.
MEEGAN, S. K. \& PERRY, S. A., 1996, Periphyton communities in headwater streams of different water chemistry in the Central Appalachian Mountains. J. Freshw. Ecol., 11: 247256.

NECCHI, O. Jr., BRANCO, C. C. Z., SIMÃO, R. C. G. \& BRANCO, L. H. Z., 1995, Distribution of stream macroalgae in the northwest region of São Paulo State, southeastern Brazil. Hydrobiologia, 299: 219-230.

NECCHI, O. Jr., BRANCO, C. C. Z. \& BRANCO, L. H. Z., 2000a, Distribution of stream macroalgae in São Paulo State, southeastern Brazil. Algol. Stud., 97: 43-57.

NECCHI, O. Jr., BRANCO, L. H. Z. \& BRANCO, C. C. Z., 2000b, Características limnológicas do Alto Rio São Francisco, Parque Nacional da Serra da Canastra, Minas Gerais. Acta Limnol. Brasil., 12: 11-22.

NECCHI, O. Jr., PASCOALOTO, D. \& BRANCO, L. H. Z., 1994, Distribution of macroalgae in a tropical river basin of southeastern Brazil. Arch. Hydrobiol., 129: 459-471.

ORMEROD, S. J., RUNDLE, S. D., WILKINSON, S. M., DALY, G. P. \& JUTTNER, I., 1994, Altitudinal trends in the diatoms, bryophytes, macroinvertebrates and fish of a Nepalese river system. Freshw. Biol., 32: 309-322.

PENTECOST, A., BAILEY, R. G., BUSUlWA, H. S. \& WILLIAMS, A., 1997, Epilithic algal communities of the Bujuku-Mubuku River system, Rwenzori Mountains, Uganda. Arch. Hydrobiol., 139: 479-493.

PFISTER, P., 1992, Artenspektrum des Algenaufwuchses in 2 Tiroler Bergbachen - Teil 1: Cyanophyceae, Chrysophyceae, Chlorophyceae, Rhodophyceae. Algol. Stud., 65: 43-61.

PFISTER, P., 1993, Seasonality of macroalgal distribution patterns within the reach of a gravel stream (Isar, Tyron, Austria). Arch. Hydrobiol., 129: 89-107.

SHEATH, R. G. \& BURKHOLDER, J. M., 1985, Characteristics of softwater streams in Rhode Island. II: Composition and seasonal dynamics of macroalgal communities. Hydrobiologia, 128: 109-118.

SHEATH, R. G. \& COLE, K. M., 1992, Biogeography of stream macroalgae in North America. J. Phycol., 28: 448-460.

SHEATH, R. G. \& HAMBROOK, J. A., 1988, Mechanical adaptations to flow in freshwater red algae. J. Phycol., 24: 107-111.

SHEATH, R. G., HAMILTON, P. B., HAMBROOK, J. A. \& COLE, K. M., 1989, Stream macroalgae of the eastern boreal forest region of North America. Can. J. Bot., 67: 3353-3362.

SHEATH, R. G., MORISON, M. O., KORCH, J. E., KACZMARCZYK, D. \& COLE, K. M., 1986, Distribution of stream macroalgae in south-central Alaska. Hydrobiologia, 135: 259-269.

SHEATH, R. G., VIS, M. L., HAMBROOK, J. A. \& COLE, K. M., 1996, Tundra stream macroalgae of North America: composition, distribution and physiological adaptations. Hydrobiologia, 336: 67-82.

TER BRAAK, C. J. F., 1986, Canonical Correspondence Analysis: a new eigenvector technique for multivariate analysis. Ecology, 67: 1667-1679. 
UEHLINGER, U., 1991, Spatial and temporal variability of the periphyton biomass of a prealpine river (Necker, Switzerland). Arch. Hydrobiol., 123: 219-231.

VAVILOVA, V. V. \& LEWIS, W. M. Jr., 1999, Temporal and altitudinal variations in the attached algal of mountain streams in Colorado. Hydrobiologia, 390: 99-106.

WARD, J. V., 1986, Altitudinal zonation in a Rocky Mountain stream. Arch. Hydrobiol., Suppl., 74: 133-199.

WARD, J. V., 1994, Ecology of alpine streams. Freshw. Biol., 32: $277-294$
WEHR, J. D., 1981, Analysis of seasonal succession of attached algae in a mountain stream, the North Alouette River, British Columbia. Can. J. Bot., 59: 1465-1474.

WHITTON, B. A., 1984, Ecology of European Rivers. Blackwell Sci. Publ., Oxford, 644p.

ZAR, J. H., 1999, Biostatistical analysis, $4^{\text {th }}$ ed. Prentice Hall, Upper Saddle River, NJ, 663p. 